\title{
Article \\ Copresence of High-Risk Human Papillomaviruses and Epstein-Barr Virus in Colorectal Cancer: A Tissue Microarray and Molecular Study from Lebanon
}

\author{
Karim Nagi 1,2,*(D), Ishita Gupta ${ }^{1,2}$, Nawaf Jurdi ${ }^{3}$, Amber Yasmeen ${ }^{4}$, Semir Vranic ${ }^{1,2} \mathbb{D}$, Gerald Batist ${ }^{4,5}$ \\ and Ala-Eddin Al Moustafa $1,2,6, *$ (D)
}

check for updates

Citation: Nagi, K.; Gupta, I.; Jurdi, N.; Yasmeen, A.; Vranic, S.; Batist, G.; Moustafa, A.-E.A. Copresence of High-Risk Human Papillomaviruses and Epstein-Barr Virus in Colorectal Cancer: A Tissue Microarray and Molecular Study from Lebanon. Int. J. Mol. Sci. 2021, 22, 8118. https://doi.org/10.3390/ ijms22158118

Academic Editors: Hidekazu Suzuki, James K. Bashkin and Luis Vicente López-Llorca

Received: 3 May 2021

Accepted: 28 June 2021

Published: 29 July 2021

Publisher's Note: MDPI stays neutral with regard to jurisdictional claims in published maps and institutional affiliations.

Copyright: (c) 2021 by the authors. Licensee MDPI, Basel, Switzerland. This article is an open access article distributed under the terms and conditions of the Creative Commons Attribution (CC BY) license (https:/ / creativecommons.org/licenses/by/ $4.0 /)$.
1 College of Medicine, QU Health, Qatar University, Doha 2713, Qatar; ishita.gupta@qu.edu.qa (I.G.); svranic@qu.edu.qa (S.V.)

2 Biomedical and Pharmaceutical Research Unit, QU Health, Qatar University, Doha 2713, Qatar

3 Department of Pathology and Laboratory Medicine, American University of Beirut Medical Center, Beirut 1107, Lebanon; nj14@aub.edu.lb

4 Segal Cancer Center/Lady Davis Institute for Medical Research, JGH/McGill University, Montreal, QC H3A 0G4, Canada; amber.yasmeen@mail.mcgill.ca (A.Y.); gerald.batist@mcgill.ca (G.B.)

5 Oncology Department, Faculty of Medicine, McGill University, Montreal, QC H3A 0G4, Canada

6 Biomedical Research Centre, QU Health, Qatar University, Doha 2713, Qatar

* Correspondence: knagi@qu.edu.qa (K.N.); aalmoustafa@qu.edu.qa (A.-E.A.M.); Tel.: +974-4403-7851 (K.N.); +974-4403-7817 (A.-E.A.M.)

\begin{abstract}
Colorectal cancer (CRC) is the third most common cause of cancer-related deaths worldwide. Human papillomaviruses (HPVs) and Epstein-Barr virus (EBV) have been reported to be present in different types of human cancers, including CRCs, where they can play a key role in the onset and/or progression of these cancers. Thus, we herein explored the prevalence of high-risk HPVs and EBV in a cohort of 94 CRC tissue samples and 13 colorectal normal tissues from the Lebanese population using polymerase chain reaction, immunohistochemistry, and tissue microarray methodologies. We found that high-risk HPVs are present in $64 \%$, while EBV is present in $29 \%$ of our CRC samples. Additionally, our data showed that high-risk HPV types (16, 18, 35, 58, 51, 45, 52, 31, and 33) are the most frequent in CRC in the Lebanese cohort, respectively. Our data point out that HPVs and EBV are copresent in $28 \%$ of the samples. Thus, this study clearly suggests that high-risk HPVs and EBV are present/copresent in CRCs, where they could play an important role in colorectal carcinogenesis. Nevertheless, further investigations using a larger cohort are needed to elucidate the possible cooperation between these oncoviruses in the development of CRC.
\end{abstract}

Keywords: Epstein-Barr virus; human papillomavirus; colorectal cancer; tumor grade; Lebanon

\section{Introduction}

Colorectal cancer (CRC) is the third most commonly diagnosed form of cancer worldwide, with more than 1.9 million new cases in 2020, which accounts for approximately $10 \%$ of all cancer cases according to the World Health Organization GLOBOCAN database [1]. CRC is considered the fourth primary cause of cancer-related deaths in males and the third foremost cause of cancer-related mortality among females [1]. CRCs are classified as inherited, inflammatory, or sporadic [2]. Sporadic cancers account for around 80\% of all CRCs, and current investigations aim to identify the underlying causative factors for the onset of sporadic CRCs [2]. Along with environmental (diet, obesity) [3,4] and genetic factors, several infectious agents, including human papillomaviruses (HPVs), are considered risk factors [5].

Around $20 \%$ of all cancers are known to be caused by infectious agents including bacterial and viral components [5]. Viral infections by small DNA viruses including polyomaviruses, HPVs, and Epstein-Barr virus (EBV) are known to be involved in several 
carcinomas such as Merkel cells, cervical cancer, Burkitt's lymphoma, Hodgkin's lymphoma, and nasopharyngeal carcinomas [4-9].

HPVs are nonenveloped, double-stranded DNA viruses that infect the basal layer of epithelial cells [5,10]. HPVs are divided into two types: low-risk and high-risk HPVs [11]. High-risk HPVs are associated with the onset and development of various epithelial cancers including cervical, anal, penile, esophageal, and vaginal [12-16]; however, the carcinogenic probability of each strain differs. Of all HPVs, types 16 and 18 are wellestablished carcinogenic viruses [17]. HPVs consist of early (E1, E2, E4, E5, E6, and E7) and late proteins (L1 and L2) [18]. The early protein E5 binds and activates epidermal growth factor receptor-1 (EGFR-1), while E6 and E7 act by impeding the activity of tumor suppressor genes $\mathrm{p} 53$ and $\mathrm{pRb}$, respectively, through their targeted destruction by various pathways, which could lead to precancer $[19,20]$. High-risk oncoproteins of HPVs E5 and E6/E7 can cooperate to initiate epithelial-to-mesenchymal transition (EMT), which is a hallmark of cancer progression [21]. Moreover, it has been demonstrated that E6/E7 oncoproteins of high-risk HPVs convert noninvasive and nonmetastatic cancer cells into invasive and metastatic ones [22]. Several studies revealed that high-risk HPVs are present in human CRCs worldwide including few countries of the Middle East (ME) region [23-26].

On the other hand, Epstein-Barr virus (EBV), entails six EBV nuclear proteins (EBNA1, $-2,-3 \mathrm{~A},-3 \mathrm{~B},-3 \mathrm{C}$, and $-\mathrm{LP}$ ), three latent membrane proteins (LMP1, $-2 \mathrm{~A}$, and $-2 \mathrm{~B}$ ), and multiple noncoding RNAs (EBERs and miRNAs) [27-29]. EBV-induced cancers involve EBV's latent cycle; these latent EBV forms (e.g., EBNA-1, EBERs, LMP-1) regulate the four types of latent gene expression (latency I, II, III, and IV) [30]. Three latency programs (Latency I, II, and III) exemplify the types of cancers associated with EBV [30,31]; latency I is frequently found in Burkitt lymphoma, while latency II is associated with nasopharyngeal carcinoma, Hodgkin's disease, and T-cell non-Hodgkin's lymphomas, while latency III generally affects immunocompromised patients [30]. Suppressed state of EBV can develop to cause several B-cell lymphomas, oral carcinomas (especially nasopharyngeal), gastric cancer, and other malignancies [30,31]. It is known that LMP1, an oncogenic protein of EBV, enhances cellular growth, inhibits apoptosis, and promotes cell motility and angiogenesis in different types of human carcinomas [32,33]. To date, there are few studies documenting the presence and/or role of EBV in human CRCs [34-41].

Recent investigations, including ours, pointed out that oncoviruses (high-risk HPVs and EBV) can be copresent in several types of human cancers, including CRCs, where they can cooperate in the initiation and progression of these cancers via the crosstalk of their oncoproteins [42-46]. Recently, copresence of HPVs and EBV was reported in 16\% of CRCs samples from Bosnia and Herzegovina [47]; however, the copresence of HPVs and EBV in CRCs in the ME region is limited to only one study from Syria [46]. This study revealed that $17 \%$ of the 102 cancer samples were positive for both of these oncoviruses [46]. Thus, we herein explore the copresences of high-risk HPVs and EBV in CRC samples from Lebanon. Our study points out that HPVs and EBV are copresent in $28 \%$ of the samples.

\section{Results}

\subsection{Clinicopathological Characteristics of the Cohort}

The study included 107 CRC samples from 37 (35\%) male and 70 (65\%) female patients. The mean age of patients is 60 years (range, 3-89 years). The plurality of specimens was taken from the rectosigmoid colon (46 cases, $49 \%$ ), while the remaining samples originated from other anatomic parts of the colon ( 48 cases, 51\%). Table 1 summarizes the clinicopathological characteristics of the cohort.

All tumors in the present study were histologically confirmed as adenocarcinomas. Of the studied cases, the majority of cancers (72 cases, $77 \%$ ) were grade 1 (low-grade), while 22 cases $(23 \%)$ were grade 2 (high-grade) (Table 1). Based on the pT stage, $6(6.4 \%)$ cases were stage $1,5(5.3 \%)$ cases stage $2,79(84 \%)$ cases stage 3 , and $4(4.3 \%)$ cases were reported to have pT4 stage disease at the time of presentation. Lymph node metastases were found in 42 cases $(44.7 \%)$ (Table 1$)$. 
Table 1. Clinicopathological characteristics of the cohort of patients with colorectal cancer.

\begin{tabular}{ccc}
\hline Characteristic & Categories & Number (\%) \\
\hline \multirow{2}{*}{ Gender } & Male & $37(34.6)$ \\
& Female & $70(65.4)$ \\
\hline \multirow{2}{*}{ Age } & $\leq 50$ & $32(29.9)$ \\
& $>50$ & $75(70.1)$ \\
\hline \multirow{2}{*}{ Tumor Location } & Recto-sigmoid colon & $46(49)$ \\
& Other parts of colon & $48(51)$ \\
\hline \multirow{2}{*}{ Tumor Grade $\varphi$} & Grade 1 (low-grade) & $72(76.6)$ \\
& Grade 2 (high-grade) & $22(23.4)$ \\
\hline \multirow{2}{*}{ Tumor Stage $\left(\right.$ pT $^{*}{ }^{*}$} & pT1 & $6(6.4)$ \\
& pT2 & $5(5.3)$ \\
& pT3 & $79(84)$ \\
Lymph Node Involvement & pT4 & $4(4.3)$ \\
(pN) & pN0 & $52(55.3)$ \\
& pN1 & $20(21.3)$ \\
& pN2 & $22(23.4)$ \\
\hline
\end{tabular}

$\bar{\varphi}$ Tumor grade is set according to the College of American Pathologists Consensus Statement [48]. * Tumor stage is based on the American Joint Committee on Cancer (AJCC) TNM system (8th edition) [49].

\subsection{Presence of High-Risk HPV Subtypes and EBV by PCR}

In total, 107 (13 normal and 94 cancer) colorectal samples had interpretable results for HPV and EBV by PCR. We found that 60 of the 94 CRC samples were positive for highrisk HPVs (63.8\%); the most commonly identified high-risk HPVs in the cohort $(n=94)$ was HPV16 (39\%), followed by HPV18 (38\%), HPV35 (29\%), HPV58 (28\%), HPV51 (26\%), HPV45 (23\%), HPV52 (21\%), HPV31 (14\%) and HPV33 (4\%) (Figure 1). HPV types 39, 56, 59,66 , and 68 were not detected in our examined samples (Figure 1).

\section{Distribution of Separate High-Risk HPV Subtypes in Colorectal Cancer}

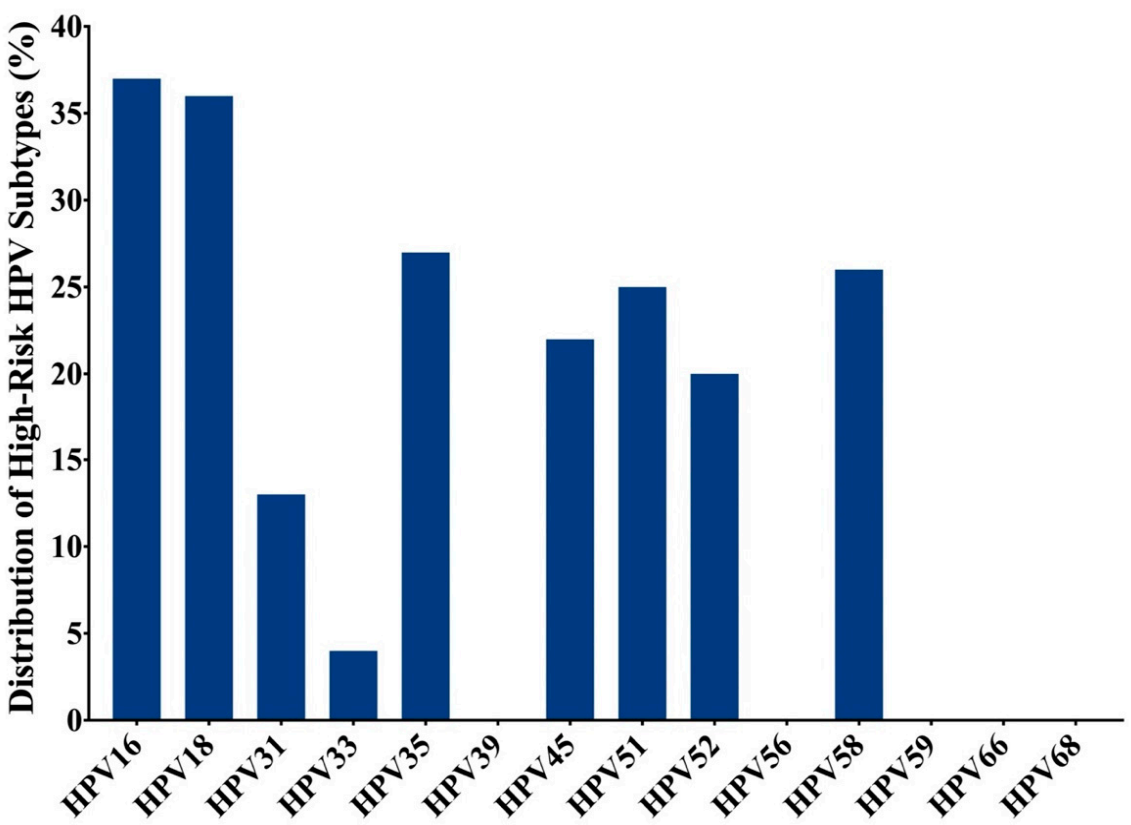

High-Risk HPV Subtypes

Figure 1. The distribution of each high-risk HPV subtype in Lebanese colorectal cancer samples. The PCR analysis included 94 colorectal cancer (CRC) samples revealing that the most frequent human papillomaviruse (HPV) subtypes are 16, 18, 35, 58, 51, 45, 52, 31, and 33. 
On the other hand, 4 of the $13 \mathrm{CR}$ normal tissues (31\%) were positive for HPV; however, a significant difference was noted in the incidence of HPV infection between CRC cases and controls $(p=0.03)$. Of the $4 \mathrm{CR}$ normal samples, none of them expressed more than one HPV type.

Furthermore, our data pointed out that $9(9.6 \%)$ CRC cases were positive for two HPV subtypes. Three or more coinfections were also detected in 40/94 (42.5\%) CRC samples; 8 cases $(8.5 \%)$ had 3 HPV coinfections, 11 cases $(11.7 \%)$ had 4 coinfections, 13 cases $(13.8 \%)$ had 5 coinfections, and 8 cases $(8.5 \%)$ revealed the presence of 6 high-risk HPV coinfections. The most commonly identified combination was HPV16/18, where $19(20.2 \%)$ of the 94 CRC samples were coinfected with both HPV16 and 18.

Regarding the presence of EBV, we noted that 27/94 (28.7\%) of the CRC samples were positive for this oncovirus, while all normal colorectal samples were negative for EBV $(p=0.03)$. Interestingly, our data revealed that while all normal colorectal samples were negative for the copresence of HPV and EBV, $26(27.6 \%)$ cancer samples were positive for both high-risk HPVs and EBV ( $p=0.03)$. However, we noted a significant association between the presence of EBV and HPV types-18 $(p<0.0001),-33(p=0.006),-35,-52$ and -58 $\left(p<0.0001\right.$, each) in our cohort of CRC samples ( $\chi^{2}$ test) (Table 2$)$.

Table 2. Correlation of EBV and HPV-subtypes in Lebanese colorectal cancer patients.

\begin{tabular}{|c|c|c|c|c|c|c|c|c|c|c|}
\hline \multirow{2}{*}{ Samples } & \multirow{2}{*}{ No. of Cases } & \multicolumn{9}{|c|}{ High-Risk HPV Types } \\
\hline & & 16 & 18 & 31 & 33 & 35 & 45 & 51 & 52 & 58 \\
\hline $\operatorname{EBV}(+)$ & 27 & 15 & 24 & 7 & 4 & 17 & 9 & 11 & 11 & 20 \\
\hline $\operatorname{EBV}(-)$ & 67 & 22 & 12 & 6 & 0 & 10 & 13 & 14 & 9 & 6 \\
\hline Total & 94 & 37 & 36 & 13 & 4 & 27 & 22 & 25 & 20 & 26 \\
\hline \multicolumn{2}{|c|}{$p$-value } & 0.07 & $<0.0001 * * *$ & 0.07 & $0.006 * *$ & $<0.0001^{* * *}$ & 0.24 & 0.09 & $<0.0001 * * *$ & $<0.0001^{* * *}$ \\
\hline
\end{tabular}

${ }^{* *}$ indicates significant $p$-values $(<0.01) ;{ }^{* * *}$ indicates significant $p$-values $(<0.001)$.

Based on the anatomical regions, 33/46 (71.7\%) rectosigmoid cancer cases were positive for HPVs, while EBV was present in 12/46 (26.1\%) of these cases. Moreover, 12/46 (26.1\%) rectosigmoid cases were positive for both high-risk HPVs and EBV. On the other hand, $27 / 48(56.3 \%)$ of the other parts of the colon cancer cases were positive for HPVs, and $15 / 48(31.3 \%)$ were positive for EBV. In addition, we found that $14 / 48(29.2 \%)$ of the other parts of the colon cancer cases exhibit copresence of HPV and EBV. However, we found no significant difference between the presence of HPV or/and EBV and anatomical locations.

\subsection{Expression Patterns of E6 and LMP1 Oncoproteins of High-Risk HPVs and EBV}

Figures 2 and 3 are representative images showing IHC expression patterns of E6 and LMP1 proteins in normal colonic mucosa (Figure 2) and colorectal carcinomas (Figure 3). Figure 2A,C (normal mucosa) and Figure 3A,B (colorectal carcinoma) are the corresponding hematoxylin and eosin (H\&E) images.

Among the 94 CRC samples used for IHC to detect E6 (high-risk HPV) and LMP1 (EBV), 22 of the tissue microarray (TMA) blocks lacked cancerous tissues, plausibly due to the lack of exact H\&E/FFPE matching required for normal TMA construction. Moreover, 45 of the remaining $72 \mathrm{CRC}$ cases (62.5\%) were positive for E6 of high-risk HPVs, as revealed by IHC analysis above the threshold of $1 \%$ of positive cancer cells (Figure 3D). On the other hand, LMP1 of EBV was expressed in 20/72 (27.7\%) of the CRC cases (Figure 3C). Only one normal mucosa was positive for HPV, while three normal cases had epithelium positive for EBV; intramucosal lymphocytes were also occasionally positive for LMP1 protein (Figure 2B,D); however, although there was a significant difference in the incidence of HPV infection between CRC cases and controls $(p=0.0008)$, whereas there was no significant difference in EBV infection between CRC cases and controls $(p=0.99)$. Copresence of HPV (E6) and EBV (LMP1) was detected in 14/72 (19.4\%) CRC cases; similarly, in our PCR data, we noted the copresence of both oncoviruses in $27 / 94$ (28.7\%) of the CRC cases. 

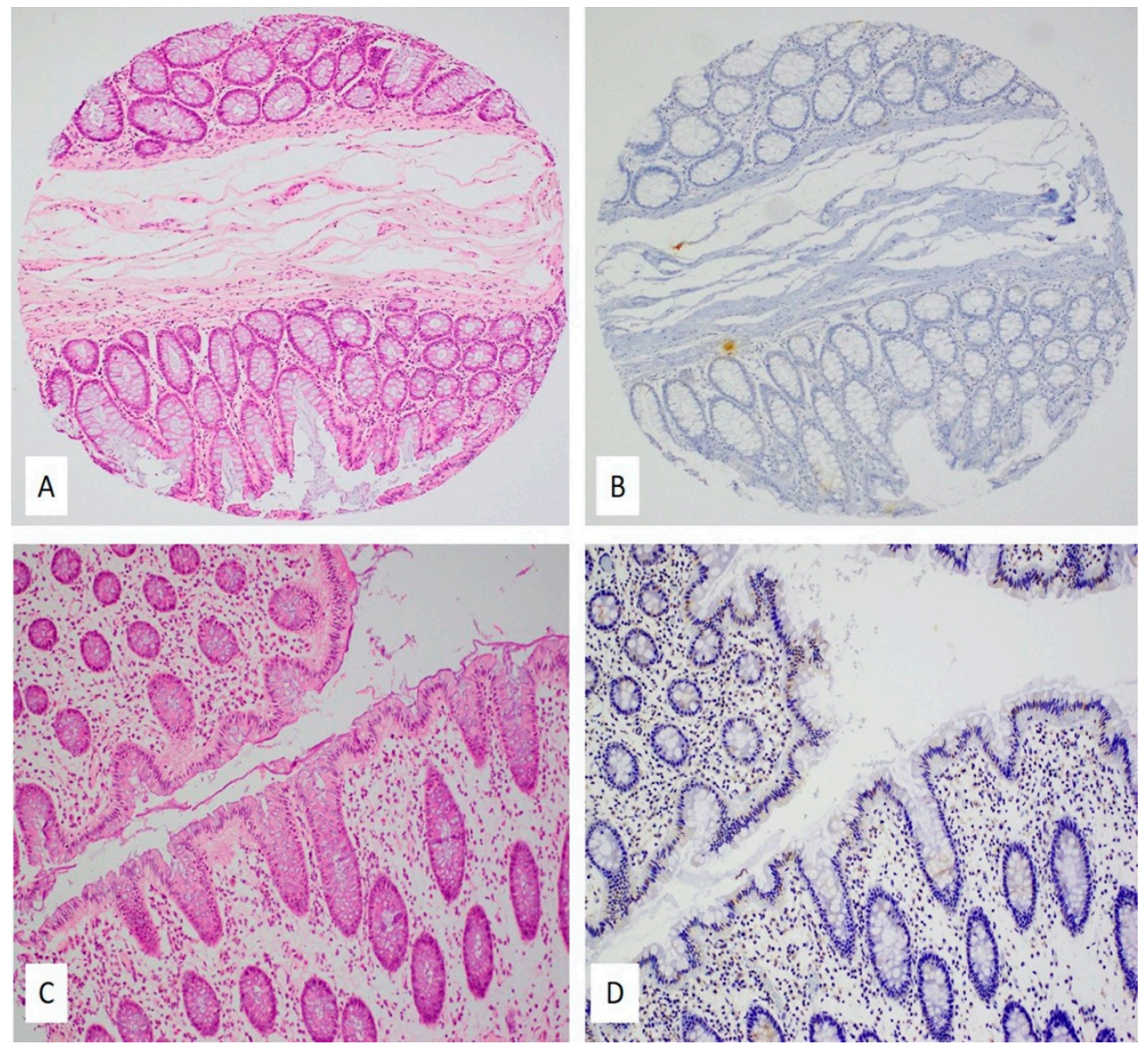

Figure 2. (A-D) HPV and EBV expression in normal colonic mucosa; $(\mathbf{A}, \mathbf{C})$ hematoxylin and eosin slides (H\&E) of two cases with normal colonic mucosa, 10×; (B,D) corresponding IHC slides for E6 protein (B) and LMP1 protein (D) revealed no protein expression in the normal colonic epithelium; however, some intramucosal lymphocytes were positive for LMP1 protein $(10 \times)$. Immunohistochemical staining was performed using the standardized avidin-biotin immunoperoxidase method.

Finally, we should highlight that IHC and PCR data for HPV and EBV are in good correlation ( 62.5 vs. $63.8 \%$ for HPV and $27.7 \%$ vs. $28.7 \%$ for EBV, respectively). Nevertheless, there is a slight discrepancy in the detection of the copresence of HPV and EBV by IHC and PCR. Such discrepancy is shared by previous studies in their results pertaining to PCR and IHC while reporting HPV and EBV positivity in cancer cases [50-52]. Hence, the discrepancy can be attributed to variation in sensitivity and reliability between PCR and IHC in detecting HPV and EBV among patient samples. 

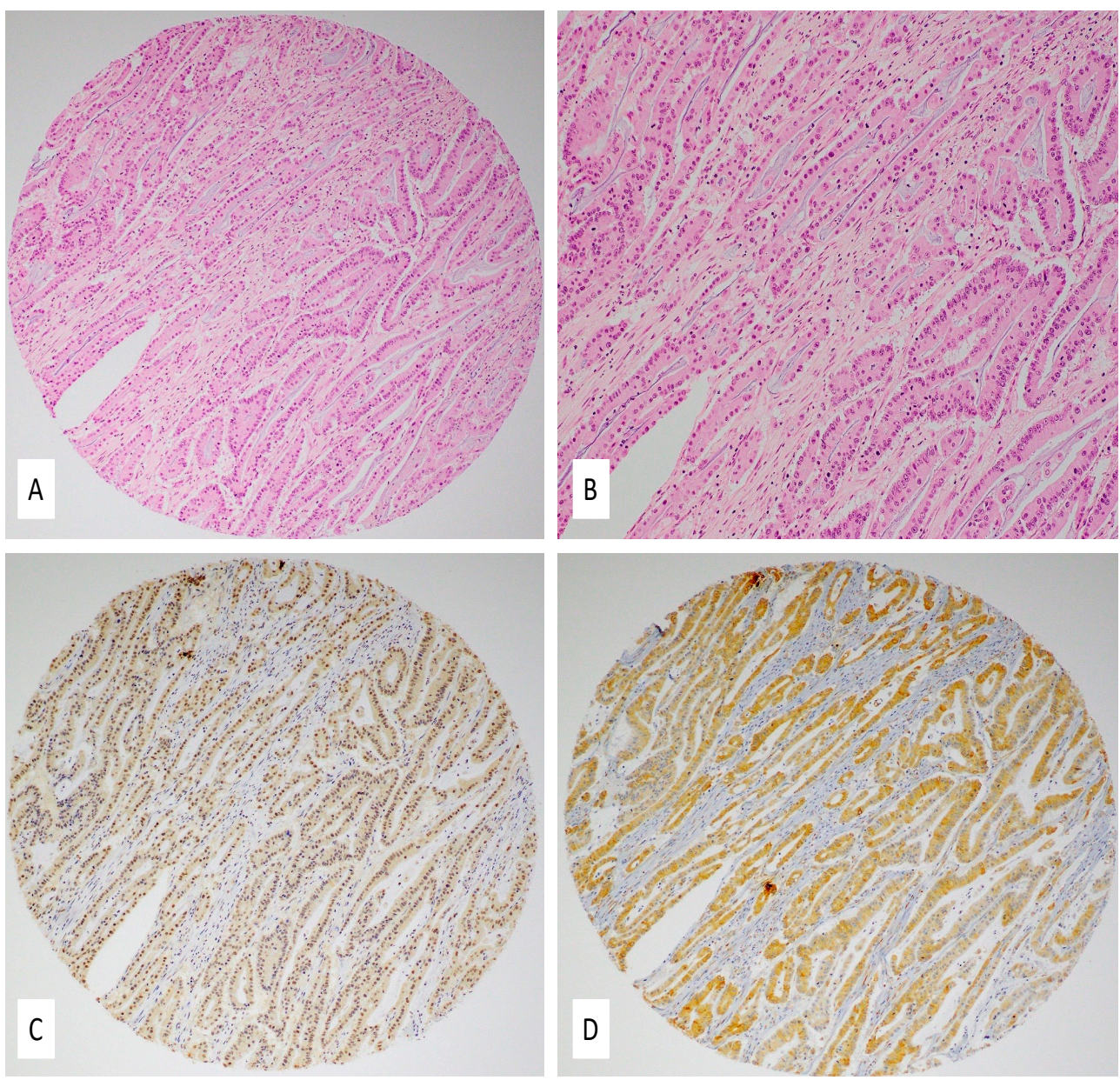

Figure 3. (A-D) Coexpression of EBV and HPV in colorectal carcinoma: $(\mathbf{A}, \mathbf{B})$ hematoxylin and eosin slides (H\&E) showing a moderately differentiated colorectal carcinoma (magnifications $10 \times$ and 20×, respectively); (C,D) IHC revealed diffused and strong LMP1 (C) and E6 protein expression (D) $(10 \times)$. Immunohistochemical staining was performed using the standardized avidin-biotin immunoperoxidase method.

\subsection{Correlation of Clinicopathological Characteristics with HPV/EBV Positivity}

In our cohort, we found no correlation between HPV positivity and tumor grade $(p=0.78)$, stage $(p=0.48)$, lymph node involvement $(p=0.63)$, or anatomical location $(p=0.18)$. Moreover, there was no correlation between EBV positivity and tumor grade $(p=0.65)$, stage $(p=0.96)$, lymph node involvement $(p=0.15)$, or anatomical location $(p=0.74)$.

The copresence of high-risk HPVs and EBV $(\mathrm{HPV}+/ \mathrm{EBV}+)$ did not correlate with tumor grade $(p=0.75)$, stage $(p=0.96)$, lymph node involvement $(p=0.21)$, or anatomical location $(p=0.81)$. This may be attributed to the small number of samples in the study.

\section{Discussion}

To the best of our knowledge, this is the first study reporting the presence/copresence of high-risk HPVs and EBV in human CRC in the Lebanese population. Our data revealed that high-risk HPVs are present in $64 \%$ of CRC samples, while normal colorectal samples revealed positivity for high-risk HPVs in 4 of 13 cases; however, a significant difference in HPV-positivity was detected between normal and tumor colorectal tissue samples $(p=0.03)$. In concordance with data obtained in the present study, a large number of investigations worldwide revealed that high-risk HPVs are present in around $40-80 \%$ of human CRC cases [53-56]. While in the ME region, the presence of HPVs is limited to 
few studies; for instance, a report from Turkey showed a high HPVs prevalence (81\%) in CRC [26]. In addition, other countries from the ME region such as Syria and Iran reported a comparatively lower frequency of HPV prevalence (33-37\%) [46,57-61]. However, an investigation conducted in Saudi Arabia reported a very low prevalence of HPV ( 1\%) in CRC samples [62]. On the other hand, and regarding HPV types in human cancers in Lebanon, previous reports revealed that the presence of HPVs varies from $6 \%$ to $76 \%$ in oropharyngeal and cervical cancers with HPV16 being the most prominent [63,64]. In our study, we found that the most frequent HPV types in CRC samples are HPVs-16, -18 , $-35,-58,-51,-45,-52,-31$, and -33 , in descending order. Similar to our data, studies from other countries in the ME region, reported HPVs-16, $-18,-51$, and -58 as the most prevalent high-risk HPV subtypes in CRC $[59,60,65,66]$. More specifically, our data are similar to data obtained in CRCs from Iran, Israel, Syria, and Turkey, where HPVs-16, -18, -31, -33, and -35 were reported as the most prominent high-risk HPV subtypes [23,46,59-61,67]. Furthermore, to understand the role of HPV in CRC pathogenesis, a study by Motlagh et al. [65] and Chen et al. [57] indicated that E6 oncoprotein of HPV type 16 silences p53 expression. Their analysis reported loss of p21 and mdm2 mRNA expression levels in E6-positive/p53mutated tumors, in comparison with adjacent normal tissues [57]. The study reports that the presence of E6 oncoprotein inactivates p53, thus reducing the expression levels of p21 and $\mathrm{mdm} 2$ [57], indicating a plausible underlying mechanism of the role of HPV in CRC pathogenesis. Moreover, a study from our group revealed that E6/E7 of HPV type 16 can transform human normal mesenchymal CR cells; thus, E6/E7 enhances the cell migration ability of these transformed cells [68]. Another investigation from our lab pointed out that E6/E7 of HPV type 16 can convert noninvasive and nonmetastatic cancer cells into invasive and metastatic ones [22]. Thus, it is likely that high-risk HPVs play an important role in the development and/or progression of human carcinomas including colorectal. On the other hand, our data showed HPV infection to be prevalent in the rectosigmoid junction and colon; this observation is consistent with the transmission of HPV to different anatomical locations through peripheral blood lymphocytes [57]. However, in concordance with other studies, we did not find any correlation between HPV infection and the anatomic location of tumors [57,69].

Vis à vis EBV in CRC, a few studies have reported EBV positivity in CRC cases ranging from $20-50 \%$ [35,39,40,70-75]; however, other studies failed to detect the presence of EBV in human CRC samples $[41,70,72,76-78]$. Accordingly, our present study in the Lebanese population showed that $27(29 \%)$ of the 94 samples are EBV positive. We also found sporadic EBV positivity in adjacent normal mucosa as well as in intramucosal lymphocytes. Our results are in accordance with data obtained using PCR and IHC in CRC samples from Bosnia (25\%) [47], China (28\%) [39], South Korea (31\%) [78], and Syria (36\%) [46]. However, while few studies reported a low prevalence of EBV positivity (1-8\%) [79-81], other studies such as those in New Guinean [82] and Italy [73] reported a prevalence of $\sim 40-50 \%$. In addition, it should be noted that other investigations from the Middle East [72] and other parts of the world [41,70,76-78,83,84] failed to detect EBV in adenocarcinoma of the colon.

In our present study, we explored the copresence of high-risk HPVs and EBV in human CRC cases in the population of Lebanon. Interestingly, it has been recently pointed out that these oncoviruses can be copresent in several types of human cancers including cervical, oral, breast, and CRC, and their copresence varies from 12 to $50 \%$ of the cases [42-47,75,85-91]. Although, various studies reported an association between EBV presence and CRC [35], evidence on the role of EBV in CRC is contradictory since the majority of studies that indicate a positive association are based on PCR or IHC assays, alone or in combination with other techniques. Nevertheless, studies based on PCR assay can plausibly be contaminated by EBV-positive inflammatory cells (lymphocytes), suggesting the presence of EBV in its latent form (LMP1) and not lytic form in lymphoid aggregates within the tumor mass [70]. However, both techniques may be biased as they primarily select/target a certain EBV gene (different primers) or protein (different antibodies); therefore, other methods such as NGS assays or in situ hybridization of EBER that have higher 
sensitivity should be used to detect EBV in colorectal and other cancers [92]. Given the presence of common nuclear expression of LMP1 protein in our cohort (in both cancer cells and lymphocytes), future work should definitely include positive immunostains (controls) such as nasopharyngeal carcinoma and classical Hodgkin lymphoma tissues. In addition, a confirmatory in situ hybridization assay for EBER should further validate our results (this assay is currently unavailable in our lab due to technical difficulties).

In addition, it has been demonstrated that the copresence of HPVs and EBV is associated with tumor grade and stage in human carcinomas [43,45-47,91]. Accordingly, we found in our study that HPVs and EBV are copresent in $28 \%$ of the CRC samples in Lebanon. However, there was no significant association between HPVs and EBV copresence with tumor grade or stage, which could be due to the limited number of samples used herein. On the other hand, it is postulated that EBV infection can cooperate with other oncoviruses in the development and progression of several human carcinomas [34,93-95]. The cooperative oncogenic effects of viral infections are considered plausible oncogenic drivers in different cancers [96]; coinfection by HPV and EBV stimulates EBV persistence either via latency, enhanced viral replication, or by triggering HPV oncogene expression [97]. Moreover, oncoproteins of HPV and EBV can lead to the development and progression of cancer via commonly linked signaling pathways including WNT/ $\beta$-catenin, JAK/STAT/SRC, PI3k/Akt/mTOR, and/or RAS/MEK/ERK [34,96,98,99]. Interestingly, based on data reported by our lab and others, copresence of high-risk HPVs and EBV is involved in the onset and progression of various cancers including colorectal, head and neck, cervical, as well as breast cancer, by the initiation and/or amplification of the EMT event [42,44-47,93,98,100-102], thus indicating a similar role in the pathogenesis of human CRC malignancy. In addition, an in vitro study indicated that oncoproteins of HPV and EBV can cooperate to stimulate proliferation and invasion of breast cancer cells via Erk1/Erk2 and $\beta$-catenin pathways [102], suggesting a plausible mechanism for colorectal cancer cells.

\section{Materials and Methods}

\subsection{Sample Collection and DNA Extraction}

All samples were taken from formalin-fixed, paraffin-embedded (FFPE) tissues of surgically removed and pathologically confirmed colorectal carcinomas. Primary and naïve colorectal cancer samples from Lebanese patients were retrieved from the private pathology archive of Dr. Nawaf Jurdi, from Lebanon. All samples and histopathology reports were deidentified, and data were analyzed anonymously. In accordance with the ethical standards and the current Lebanese legislation, practicing physicians can orally inform all patients about the potential utilization of biopsy samples for research or secondary purposes. Therefore, written informed consent was not required. Additionally, the Institutional Biosafety Committee (IBC) approval was obtained from Qatar University (QU-IBC-2018/22) to investigate the presence of HPV and EBV in human CRCs.

All tumor samples were graded according to the American Pathologists Consensus Statement [48] using the two-tiered grading system (grade 1 and grade 2). Briefly, grade 1 (low-grade) combines well and moderately differentiated adenocarcinomas, while grade 2 (high-grade) refers to poorly differentiated and undifferentiated adenocarcinomas. The tumor stage is identified according to the American Joint Committee on Cancer (AJCC) TNM system (eighth edition) [49].

Punch samples of $2 \mathrm{~mm}$ thickness were obtained from the FFPE blocks of surgically removed and pathologically confirmed colorectal carcinomas. The Thermo Scientific GeneJET FFPE DNA Purification Kit was used to extract DNA from FFPE tissue samples in accordance with the manufacturer's instructions (ThermoFisher Scientific, Waltham, MA, USA), as previously described by our group [47]. 


\section{2. $H P V$ and EBV Detection by PCR}

Purified genomic DNA (25 ng) extracted from each sample was analyzed for HPV and EBV by PCR using specific primers for HPV types $(16,18,31,33,35,39,45,51,52,56,58$, 59,66 , and 68) of the E6/E7 region and for LMP1 gene of EBV, as previously described [47]. GAPDH was used as an internal control. Analysis was performed as previously described by our group $[103,104]$.

The Invitrogen Platinum II Hot-Start Green PCR Master Mix $(2 \times)$ (ThermoFisher Scientific, USA) was used to carry out PCR, as performed previously [47]. The PCR product from each exon was resolved using 1.5\% agarose gel electrophoresis.

\subsection{Tissue Microarray (TMA)}

Tissue microarray was constructed as previously described by our group $[42,44,100]$. In brief, using a manual tissue arrayer (Beecher Instruments, Silver Spring, MD, USA), both control and cancer cases were implanted into a virgin paraffin TMA block.

A duplicate of $1 \mathrm{~mm}$ diameter TMA cores was sampled from areas of the tumor within donor blocks from a cohort of 107 samples (13 normal and 94 cancer samples). Subsequently, sections of $4 \mu \mathrm{m}$ were sliced and subjected to hematoxylin and eosin staining on the initial slides to confirm the histopathologic diagnosis. Immunohistochemistry (IHC) assays were performed on the slides of the completed blocks against E6 and LMP1 of high-risk HPV and EBV, respectively.

\subsection{Immunohistochemistry (IHC)}

Immunohistochemical (IHC) analysis was performed on CRC samples by analyzing adjoining sections for E6 and LMP1 oncoproteins of high-risk HPV and EBV, respectively, using monoclonal antibodies for E6 of HPV (clones 1-4 and C1P5, Dako Agilent, Carpinteria, CA, USA and Calbiochem, ON, Canada) and LMP1 of EBV (clone CS1-4, Abcam, Abcam, Cambridge, MA, USA). Then, antigen retrieval in $10 \mathrm{mM}$ citrate sodium citrate solution [pH 6] (Invitrogen, Carlsbad, CA, USA) and endogenous peroxidase activity was blocked with a solution of $3 \%$ hydrogen peroxide in methanol, and TMA slides were incubated for $35 \mathrm{~min}$ at $37^{\circ} \mathrm{C}$ with primary antibody using a fully automated immunostainer (Ventana Medical System, Tuscon, AZ, USA). Prior to mounting, slides were counterstained with hematoxylin and eosin staining was completed in accordance with the manufacturer's recommendations. Negative controls were processed by omitting the specific primary antibody for E6 and LMP1.

If cancer cells showed positivity in $\geq 1 \%$ of the cells, the tumors were considered positive for E6 and LMP1 [44]. LMP1 protein expression (EBV) was also analyzed in tumor-infiltrating lymphocytes and stromal cells [44]. However, since PCR is more sensitive, as compared to IHC, data from PCR were considered reliable and were used for correlation analysis.

\subsection{Statistical Analysis}

Statistical analysis was carried out using IBM Statistical Package for the Social Sciences (version 25). We also performed the $\chi^{2}$ test, along with Yates' correction and Fisher's exact tests, to assess the significance of HPVs and EBV correlation with clinicopathological data (gender, age, tumor location, stage, and grade). Graphs were plotted using GraphPad Prism software (version 8.4.3), and statistical significance was achieved at $p<0.05$.

\section{Conclusions}

In conclusion, we explored in this study the presence/copresence of high-risk HPVs and EBV in CRC samples from Lebanon. We found that HPVs are dominant in CRC samples, while the presence of EBV was comparatively low. Furthermore, the copresence of both, HPVs and EBV, was observed in $28 \%$ of the cases; however, we did not find a correlation between copresence of HPVs and EBV with tumor grade or stage, which may be due to the limited number of samples in the cohort. Nevertheless, we believe that 
available HPV vaccines and upcoming EBV vaccines can be used to prevent part of CRC cases. Moreover, additional studies are vital to elucidate the underlying mechanisms of the cooperative role of high-risk HPVs and EBV in the initiation and/or progression of human CRC.

Author Contributions: Conceptualization, A.-E.A.M. and K.N.; methodology, I.G. and A.Y.; validation, I.G. and S.V.; formal analysis, K.N., I.G. and S.V.; resources, K.N., N.J. and G.B.; data curation, K.N., I.G. and S.V.; writing—original draft preparation, I.G.; writing-review and editing, A.-E.A.M., K.N. and S.V.; supervision, A.-E.A.M. and K.N.; funding acquisition, A.-E.A.M. All authors have read and agreed to the published version of the manuscript.

Funding: This research was funded by grants from Qatar University: QUHI-CMED-19/20-1 and QUCG-CMED-20/21-2.

Institutional Review Board Statement: The study was conducted according to the guidelines of the Declaration of Helsinki and approved by the Institutional Biosafety Committee (IBC) from Qatar University (QU-IBC-2018/22).

Informed Consent Statement: Patient consent was waived in accordance with the ethical standards and the current Lebanese legislation in which practicing physicians can orally inform all patients about the potential utilization of biopsy samples for research or secondary purposes.

Acknowledgments: We would like to thank A. Kassab for her critical reading of the manuscript.

Conflicts of Interest: The authors declare no conflict of interest. The funders had no role in the design of the study; in the collection, analyses, or interpretation of data; in the writing of the manuscript, or in the decision to publish the results.

\section{References}

1. Ferlay, J.; Colombet, M.; Soerjomataram, I.; Mathers, C.; Parkin, D.M.; Piñeros, M.; Znaor, A.; Bray, F. Estimating the global cancer incidence and mortality in 2018: GLOBOCAN sources and methods. Int. J. Cancer 2019, 144, 1941-1953. [CrossRef]

2. De Rosa, M.; Pace, U.; Rega, D.; Costabile, V.; Duraturo, F.; Izzo, P.; Delrio, P. Genetics, diagnosis and management of colorectal cancer (Review). Oncol. Rep. 2015, 34, 1087-1096. [CrossRef]

3. Thrift, A.P.; Gong, J.; Peters, U.; Chang-Claude, J.; Rudolph, A.; Slattery, M.L.; Chan, A.T.; Locke, A.E.; Kahali, B.; Justice, A.E.; et al. Mendelian Randomization Study of Body Mass Index and Colorectal Cancer Risk. Cancer Epidemiol. Biomark. Prev. 2015, 24, 1024-1031. [CrossRef]

4. Johnson, C.M.; Wei, C.; Ensor, J.E.; Smolenski, D.J.; Amos, C.I.; Levin, B.; Berry, D.A. Meta-analyses of colorectal cancer risk factors. Cancer Causes Control 2013, 24, 1207-1222. [CrossRef]

5. Antonic, V.; Stojadinovic, A.; Kester, K.E.; Weina, P.J.; Brücher, B.L.; Protic, M.; Avital, I.; Izadjoo, M. Significance of Infectious Agents in Colorectal Cancer Development. J. Cancer 2013, 4, 227-240. [CrossRef]

6. Venuti, A.B.G.; Rizzo, C.; Mafera, B.; Rahimi, S.; Vigili, M. Presence of HPV in head and neck tumours: High prevalence in tonsillar localization. J. Exp. Clin. Cancer Res. 2004, 23, 561-566. [PubMed]

7. Daling, J.R.; Madeleine, M.M.; Johnson, L.G.; Schwartz, S.M.; Shera, K.A.; Wurscher, M.A.; Carter, J.J.; Porter, P.L.; Galloway, D.A.; McDougall, J.K. Human papillomavirus, smoking, and sexual practices in the etiology of anal cancer. Cancer 2004, 101, 270-280. [CrossRef] [PubMed]

8. Ragin, C.; Taioli, E. Survival of squamous cell carcinoma of the head and neck in relation to human papillomavirus infection: Review and meta-analysis. Int. J. Cancer 2007, 121, 1813-1820. [CrossRef] [PubMed]

9. Shi, Y.; Peng, S.-L.; Yang, L.-F.; Chen, X.; Tao, Y.-G.; Cao, Y. Co-infection of Epstein-Barr virus and human papillomavirus in human tumorigenesis. Chin. J. Cancer 2016, 35, 16. [CrossRef]

10. Motoyama, S.; Ladines-Llave, C.A.; Luis Villanueva, S.; Maruo, T. The role of human papilloma virus in the molecular biology of cervical carcinogenesis. Kobe J. Med. Sci. 2004, 50, 9-19.

11. Heck, D.V.; Yee, C.L.; Howley, P.M.; Münger, K. Efficiency of binding the retinoblastoma protein correlates with the transforming capacity of the E7 oncoproteins of the human papillomaviruses. Proc. Natl. Acad. Sci. USA 1992, 89, 4442-4446. [CrossRef] [PubMed]

12. Castellsagué, X.; Díaz, M.; de Sanjosé, S.; Muñoz, N.; Herrero, R.; Franceschi, S.; Peeling, R.W.; Ashley, R.; Smith, J.S.; Snijders, P.J.; et al. International Agency for Research on Cancer Multicenter Cervical Cancer Study Group Worldwide human papillomavirus etiology of cervical adenocarcinoma and its cofactors: Implications for screening and prevention. J. Natl. Cancer Inst. 2006, 98, 303-315. [CrossRef]

13. Poletti, P.A.; Halfon, A.; Marti, M.C. Papillomavirus and anal carcinoma. Int. J. Colorectal Dis. 1998, 13, 108-111. [CrossRef]

14. Yu, Y.-B.; Wang, Y.-H.; Yang, X.-C.; Zhao, Y.; Wang, M.-L.; Liang, Y.; Niu, H.-T. The relationship between human papillomavirus and penile cancer over the past decade: A systematic review and meta-analysis. Asian J. Androl. 2019, 21, 375-380. [CrossRef] 
15. Ludmir, E.B.; Stephens, S.J.; Palta, M.; Willett, C.G.; Czito, B.G. Human papillomavirus tumor infection in esophageal squamous cell carcinoma. J. Gastrointest. Oncol. 2015, 6, 287-295. [CrossRef] [PubMed]

16. Insinga, R.P.; Liaw, K.-L.; Johnson, L.G.; Madeleine, M.M. A systematic review of the prevalence and attribution of human papillomavirus types among cervical, vaginal, and vulvar precancers and cancers in the United States. Cancer Epidemiol. Biomark. Prev. 2008, 17, 1611-1622. [CrossRef]

17. Kado, S.; Kawamata, Y.; Shino, Y.; Kasai, T.; Kubota, K.; Iwasaki, H.; Fukazawa, I.; Takano, H.; Nunoyama, T.; Mitsuhashi, A.; et al. Detection of Human Papillomaviruses in Cervical Neoplasias Using Multiple Sets of Generic Polymerase Chain Reaction Primers. Gynecol. Oncol. 2001, 81, 47-52. [CrossRef] [PubMed]

18. Al Moustafa, A.-E.; Al-Awadhi, R.; Missaoui, N.; Adam, I.; Durusoy, R.; Ghabreau, L.; Akil, N.; Ahmed, H.G.; Yasmeen, A.; Alsbeih, G. Human papillomaviruses-related cancers.Presence and Prevention Strategies in the Middle East and North African Regions. Hum. Vaccines Immunother. 2014, 10, 1812-1821. [CrossRef]

19. Huibregtse, J.; Scheffner, M.; Howley, P.M. Cloning and expression of the cDNA for E6-AP, a protein that mediates the interaction of the human papillomavirus E6 oncoprotein with p53. Mol. Cell. Biol. 1993, 13, 775-784. [CrossRef] [PubMed]

20. Scheffner, M.; Münger, K.; Huibregtse, J.M.; Howley, P.M. Targeted degradation of the retinoblastoma protein by human papillomavirus E7-E6 fusion proteins. EMBO J. 1992, 11, 2425-2431. [CrossRef]

21. Al Moustafa, A.-E. E5 and E6/E7 of high-risk HPVs cooperate to enhance cancer progression through EMT initiation. Cell Adh. Migr. 2015, 9, 392-393. [CrossRef] [PubMed]

22. Yasmeen, A.; Bismar, T.A.; Kandouz, M.; Foulkes, W.D.; Desprez, P.-Y.; Al Moustafa, A.-E. E6/E7 of HPV Type 16 Promotes Cell Invasion and Metastasis of Human Breast Cancer Cells. Cell Cycle 2007, 6, 2038-2042. [CrossRef]

23. Ghabreau, L.; Segal, E.; Yasmeen, A.; Kassab, A.; Akil, N.; Al Moustafa, A.-E. High-risk human papillomavirus infections in colorectal cancer in the Syrian population and their association with Fascin, Id-1 and P-cadherin expressions: A tissue microarray study. Clin. Cancer Investig. J. 2012, 1, 26-30. [CrossRef]

24. Yavuzer, D.; Karadayi, N.; Salepci, T.; Baloglu, H.; Dabak, R.; Bayramicli, O.U. Investigation of human papillomavirus DNA in colorectal carcinomas and adenomas. Med. Oncol. 2011, 28, 127-132. [CrossRef] [PubMed]

25. Buyru, N.; Tezol, A.; Dalay, N. Coexistence of K-ras mutations and HPV infection in colon cancer. BMC Cancer 2006, 6, 115. [CrossRef]

26. Salepci, T.; Yazici, H.; Dane, F.; Topuz, E.; Dalay, N.; Onat, H.; Aykan, F.; Seker, M.; Aydiner, A. Detection of human papillomavirus DNA by polymerase chain reaction and southern blot hybridization in colorectal cancer patients. Off. J. Balk. Union Oncol. 2009, 14, 495-499.

27. Young, L.S.; Rickinson, A.B. Epstein-Barr virus: 40 years on. Nat. Rev. Cancer 2004, 4, 757-768. [CrossRef]

28. Middeldorp, J.M.; Brink, A.A.; van den Brule, A.J.; Meijer, C.J. Pathogenic roles for Epstein-Barr virus (EBV) gene products in EBV-associated proliferative disorders. Crit. Rev. Oncol./Hematol. 2003, 45, 1-36. [CrossRef]

29. Murata, T.; Tsurumi, T. Switching of EBV cycles between latent and lytic states. Rev. Med. Virol. 2014, 24, 142-153. [CrossRef]

30. Thompson, M.P.; Kurzrock, R. Epstein-Barr Virus and Cancer. Clin. Cancer Res. 2004, 10, 803-821. [CrossRef]

31. Münz, C.; Moormann, A. Immune escape by Epstein-Barr virus associated malignancies. Semin. Cancer Biol. 2008, 18, 381-387. [CrossRef] [PubMed]

32. Shimakage, M.; Horii, K.; Tempaku, A.; Kakudo, K.; Shirasaka, T.; Sasagawa, T. Association of Epstein-Barr virus with oral cancers. Hum. Pathol. 2002, 33, 608-614. [CrossRef]

33. Horiuchi, K.; Mishima, K.; Ichijima, K.; Sugimura, M.; Ishida, T.; Kirita, T. Epstein-Barr virus in the proliferative diseases of squamous epithelium in the oral cavity. Oral Surg. Oral Med. Oral Pathol. Oral Radiol. Endodontol. 1995, 79, 57-63. [CrossRef]

34. Al-Antary, N.; Farghaly, H.; Aboulkassim, T.; Yasmeen, A.; Akil, N.; Al Moustafa, A.-E. Epstein-Barr virus and its association with Fascin expression in colorectal cancers in the Syrian population: A tissue microarray study. Hum. Vaccines Immunother. 2017, 13, 1573-1578. [CrossRef]

35. Bedri, S.; Sultan, A.A.; Alkhalaf, M.; Al Moustafa, A.-E.; Vranic, S. Epstein-Barr virus (EBV) status in colorectal cancer: A mini review. Hum. Vaccines Immunother. 2019, 15, 603-610. [CrossRef]

36. Habib, M.A. The possible role of EBV in carcinogenesis of colorectal carcinoma. Fac. Med. Baghdad 2010, 52, 172-174.

37. Liu, H.; Ding, Y.Q.; Li, X.; Yao, K.T. Investigation of Epstein-barr virus in Chinese colorectal tumors. World J. Gastroenterol. 2003, 9 , 2464-2468. [CrossRef]

38. Mehrabani-Khasraghi, S.; Ghane, M.; Ameli, M. Detection of Epstein-Barr virus in colorectal cancer and Polyp by using PCR technique. J. Paramed. Sci. 2014, 5, 96-101.

39. Song, L.-B.; Zhang, X.; Zhang, C.-Q.; Zhang, Y.; Pan, Z.-Z.; Liao, W.-T.; Li, M.-Z.; Zeng, M.-S. Infection of Epstein-Barr virus in colorectal cancer in Chinese. Chin. J. Cancer 2006, 25, 1356-1360.

40. Tafvizi, F.; Fard, Z.T.; Assareh, R. Epstein-Barr virus DNA in colorectal carcinoma in Iranian patients. Pol. J. Pathol. 2015, 66, 154-160. [CrossRef]

41. Yuen, S.; Chung, L.P.; Leung, S.Y.; Luk, I.S.; Chan, S.Y.; Ho, J. In situ detection of Epstein-Barr virus in gastric and colorectal adenocarcinomas. Am. J. Surg. Pathol. 1994, 18, 1158-1163. [CrossRef]

42. Al Moustafa, A.-E.; Al-Antary, N.; Aboulkassim, T.; Akil, N.; Batist, G.; Yasmeen, A. Co-prevalence of Epstein-Barr virus and high-risk human papillomaviruses in Syrian women with breast cancer. Hum. Vaccines Immunother. 2016, 12, 1936-1939. [CrossRef] 
43. Al-Thawadi, H.; Gupta, I.; Jabeen, A.; Skenderi, F.; Aboulkassim, T.; Yasmeen, A.; Malki, M.I.; Batist, G.; Vranic, S.; Al Moustafa, A.E. Co-Presence of Human Papillomaviruses and Epstein-Barr Virus is Linked with Advanced Tumor Stage: A Tissue Microarray Study in Head and Neck Cancer Patients. Cancer Cell Int. 2020, 20, 361. [CrossRef]

44. Al-Thawadi, H.; Ghabreau, L.; Aboulkassim, T.; Yasmeen, A.; Vranic, S.; Batist, G.; Al Moustafa, A.-E. Co-Incidence of Epstein-Barr Virus and High-Risk Human Papillomaviruses in Cervical Cancer of Syrian Women. Front. Oncol. 2018, 8, 250. [CrossRef] [PubMed]

45. Gupta, I.; Jabeen, A.; Al-Sarraf, R.; Farghaly, H.; Vranic, S.; Sulta, A.A.; Al Moustafa, A.-E.; Al-Thawadi, H. The co-presence of high-risk human papillomaviruses and Epstein-Barr virus is linked with tumor grade and stage in Qatari women with breast cancer. Hum. Vaccines Immunother. 2020, 17, 982-989. [CrossRef] [PubMed]

46. Malki, M.I.; Gupta, I.; Fernandes, Q.; Aboulkassim, T.; Yasmeen, A.; Vranic, S.; Al Moustafa, A.E.; Al-Thawadi, H.A. Co-presence of Epstein-Barr virus and high-risk human papillomaviruses in Syrian colorectal cancer samples. Hum. Vaccines Immunother. 2020, 16, 2403-2407. [CrossRef] [PubMed]

47. Gupta, I.; Al Farsi, H.; Jabeen, A.; Skenderi, F.; Al-Thawadi, H.; AlAhmad, Y.M.; Abdelhafez, I.; Al Moustafa, A.-E.; Vranic, S. High-Risk Human Papillomaviruses and Epstein-Barr Virus in Colorectal Cancer and Their Association with Clinicopathological Status. Pathogens 2020, 9, 452. [CrossRef]

48. Compton, C.C.; Fielding, L.P.; Burgart, L.J.; Conley, B.; Cooper, H.S.; Hamilton, S.R.; Hammond, M.E.; Henson, D.E.; Hutter, R.V.; Nagle, R.B.; et al. Prognostic factors in colorectal cancer. College of American Pathologists Consensus Statement 1999. Arch. Pathol. Lab. Med. 2000, 124, 979-994. [CrossRef]

49. Weiser, M.R. AJCC 8th Edition: Colorectal Cancer. Ann. Surg. Oncol. 2018, 25, 1454-1455. [CrossRef] [PubMed]

50. Awan, M.S.; Irfan, B.; Zahid, I.; Mirza, Y.; Ali, S.A. Comparison of Polymerase Chain Reaction and Immunohistochemistry Assays for Analysing Human Papillomavirus Infection in Oral Squamous Cell Carcinoma. J. Clin. Diagn. Res. 2017, 11, XC10-XC13. [CrossRef]

51. Chan, K.H.; Ng, M.H.; Seto, W.H.; Peiris, J.S.M. Epstein-Barr Virus (EBV) DNA in Sera of Patients with Primary EBV Infection. J. Clin. Microbiol. 2001, 39, 4152-4154. [CrossRef] [PubMed]

52. Qi, Z.-L.; Han, X.-Q.; Hu, J.; Wang, G.-H.; Gao, J.-W.; Wang, X.; Liang, D.-Y. Comparison of three methods for the detection of Epstein-Barr virus in Hodgkin's lymphoma in paraffin-embedded tissues. Mol. Med. Rep. 2013, 7, 89-92. [CrossRef] [PubMed]

53. Ala-Eddin, A.M.; Noor, A.-A.; Amber, Y. High-Risk Human Papillomavirus and Colorectal Carcinogenesis, Human Papillomavirus-Research in a Global Perspective. In High-Risk Human Papillomavirus and Colorectal Carcinogenesis; Rajkumar, R., Ed.; Intech Open: London, UK, 2016. [CrossRef]

54. Bernabe-Dones, R.D.; Gonzalez-Pons, M.; Villar-Prados, A.; Lacourt-Ventura, M.; Rodríguez-Arroyo, H.; Fonseca-Williams, S.; Velazquez, F.E.; Diaz-Algorri, Y.; Lopez-Diaz, S.M.; Rodríguez, N.; et al. High Prevalence of Human Papillomavirus in Colorectal Cancer in Hispanics: A Case-Control Study. Gastroenterol. Res. Pract. 2016, 2016, 7896716. [CrossRef] [PubMed]

55. Bodaghi, S.; Yamanegi, K.; Xiao, S.-Y.; Da Costa, M.; Palefsky, J.M.; Zheng, Z.-M. Colorectal papillomavirus infection in patients with colorectal cancer. Clin. Cancer Res. 2005, 11, 2862-2867. [CrossRef]

56. Damin, D.C.; Caetano, M.B.; Rosito, M.A.; Schwartsmann, G.; Damin, A.S.; Frazzon, A.P.; Ruppenthal, R.D.; Alexandre, C.O.P. Evidence for an association of human papillomavirus infection and colorectal cancer. Eur. J. Surg. Oncol. 2007, 33, 569-574. [CrossRef] [PubMed]

57. Chen, T.-H.; Huang, C.-C.; Yeh, K.-T.; Chang, S.-H.; Chang, S.-W.; Sung, W.-W.; Cheng, Y.-W.; Lee, H. Human papilloma virus 16 E6 oncoprotein associated with p53 inactivation in colorectal cancer. World J. Gastroenterol. 2012, 18, 4051-4058. [CrossRef] [PubMed]

58. Liu, F.; Mou, X.; Zhao, N.; Lin, J.; Teng, L.; Xiang, C. Prevalence of human papillomavirus in Chinese patients with colorectal cancer. Colorectal Dis. 2011, 13, 865-871. [CrossRef]

59. Mahmoudvand, S.; Safaei, A.; Erfani, N.; Sarvari, J. Presence of Human Papillomavirus DNA in Colorectal Cancer Tissues in Shiraz, Southwest Iran. Asian Pac. J. Cancer Prev. 2015, 16, 7883-7887. [CrossRef]

60. Malekpour Afshar, R.; Deldar, Z.; Mollaei, H.R.; Arabzadeh, S.A.; Iranpour, M. Evaluation of HPV DNA positivity in colorectal cancer patients in Kerman, Southeast Iran. Asian Pac. J. Cancer Prev. 2018, 19, 193-198. [CrossRef]

61. Meshkat, M.; Tayyebi Meibodi, N.; Sepahi, S.; Fadaee, N.; Salehpour, M.; Meshkat, Z. The frequency of human papillomaviruses in colorectal cancer samples in Mashhad, northeastern Iran. Turk. J. Med. Sci. 2014, 44, 501-503. [CrossRef]

62. Gazzaz, F.; Mosli, M.H.; Jawa, H.; Sibiany, A. Detection of human papillomavirus infection by molecular tests and its relation to colonic polyps and colorectal cancer. Saudi Med. J. 2016, 37, 256-261. [CrossRef] [PubMed]

63. Maroun, C.A.; Al Feghali, K.; Traboulsi, H.; Dabbous, H.; Abbas, F.; Dunya, G.; Ziade, G.; Mahfouz, R.; Youssef, B.; Tamim, $\mathrm{H}$;; et al. HPV-related oropharyngeal cancer prevalence in a middle eastern population using E6/E7 PCR. Infect. Agent Cancer 2020, 15, 1. [CrossRef] [PubMed]

64. Mroueh, A.M.; Seoud, M.A.; Kaspar, H.G.; Zalloua, P.A. Prevalence of genital human papillomavirus among Lebanese women. Eur. J. Gynaecol. Oncol. 2002, 23, 429-432.

65. Motlagh, A.; Azadeh, P.; Hashemi, M.; Molaei, M.; MajidSheibani, K.; Alidoosti, A.; Fazlalizadeh, A.; Shafaghi, B.; Fudazi, M.; Valaei, N.; et al. Human Papillomavirus Infection, p53 Overexpression and Histopathologic Characteristics in Colorectal Cancer. Govaresh 2012, 12, 8. 
66. Tanzi, E.; Bianchi, S.; Frati, E.R.; Amicizia, D.; Martinelli, M.; Bragazzi, N.L.; Brisigotti, M.P.; Colzani, D.; Fasoli, E.; Zehender, G.; et al. Human papillomavirus detection in paraffin-embedded colorectal cancer tissues. J. Gen. Virol. 2015, 96, 206-209. [CrossRef] [PubMed]

67. Karbalaie Niya, M.H.; Keyvani, H.; Safarnezhad Tameshkel, F.; Salehi-Vaziri, M.; Teaghinezhad-S, S.; Bokharaei Salim, F.; Monavari, S.H.R.; Javanmard, D. Human Papillomavirus Type 16 Integration Analysis by Real-time PCR Assay in Associated Cancers. Transl. Oncol. 2018, 11, 593-598. [CrossRef]

68. Ricciardi, R.; Ghabreau, L.; Yasmeen, A.; Darnel, A.D.; Akil, N.; Al Moustafa, A.E. Role of E6/E7 onco-proteins of high-risk human papillomaviruses in human colorectal carcinogenesis. Cell Cycle 2009, 8, 1964-1965. [CrossRef]

69. Soto, Y.; Limia, C.M.; González, L.; Grá, B.; Hano, O.M.; Martínez, P.A.; Kourí, V. Molecular evidence of high-risk human papillomavirus infection in colorectal tumours from Cuban patients. Memórias Inst. Oswaldo Cruz 2016, 111, 731-736. [CrossRef]

70. Fiorina, L.; Ricotti, M.; Vanoli, A.; Luinetti, O.; Dallera, E.; Riboni, R.; Paolucci, S.; Brugnatelli, S.; Paulli, M.; Pedrazzoli, P.; et al Systematic analysis of human oncogenic viruses in colon cancer revealed EBV latency in lymphoid infiltrates. Infect. Agent Cancer 2014, 9, 18. [CrossRef] [PubMed]

71. Karpinski, P.; Myszka, A.; Ramsey, D.; Kielan, W.; Sasiadek, M.M. Detection of viral DNA sequences in sporadic colorectal cancers in relation to CpG island methylation and methylator phenotype. Tumour. Biol. 2011, 32, 653-659. [CrossRef] [PubMed]

72. Mehrabani-Khasraghi, S.; Ameli, M.; Khalily, F. Demonstration of Herpes Simplex Virus, Cytomegalovirus, and Epstein-Barr Virus in Colorectal Cancer. Iran. Biomed. J. 2016, 20, 302-306. [CrossRef]

73. Militello, V.; Trevisan, M.; Squarzon, L.; Biasolo, M.A.; Rugge, M.; Militello, C.; Palù, G.; Barzon, L. Investigation on the presence of polyomavirus, herpesvirus, and papillomavirus sequences in colorectal neoplasms and their association with cancer. Int. J. Cancer 2009, 124, 2501-2503. [CrossRef]

74. Park, J.M.; Choi, M.-G.; Kim, S.W.; Chung, I.-S.; Yang, C.W.; Kim, Y.S.; Jung, C.K.; Lee, K.Y.; Kang, J.-H. Increased Incidence of Colorectal Malignancies in Renal Transplant Recipients: A Case Control Study. Am. J. Transplant. 2010, 10, 2043-2050. [CrossRef]

75. Salyakina, D.; Tsinoremas, N.F. Viral expression associated with gastrointestinal adenocarcinomas in TCGA high-throughput sequencing data. Hum. Genom. 2013, 7, 23. [CrossRef]

76. Kijima, Y.; Hokita, S.; Takao, S.; Baba, M.; Natsugoe, S.; Yoshinaka, H.; Aridome, K.; Otsuji, T.; Itoh, T.; Tokunaga, M.; et al. Epstein-Barr virus involvement is mainly restricted to lymphoepithelial type of gastric carcinoma among various epithelial neoplasms. J. Med. Virol. 2001, 64, 513-518. [CrossRef] [PubMed]

77. Boguszakova, L.; Hirsch, I.; Brichacek, B.; Faltyn, J.; Fric, P.; Dvorakova, H.; Vonka, V. Absence of cytomegalovirus, Epstein-Barr virus, and papillomavirus DNA from adenoma and adenocarcinoma of the colon. Acta Virol. 1988, 32, 303-308. [PubMed]

78. Cho, Y.J.; Chang, M.S.; Park, S.H.; Kim, H.S.; Kim, W.H. In situ hybridization of Epstein-Barr virus in tumor cells and tumorinfiltrating lymphocytes of the gastrointestinal tract. Hum. Pathol. 2001, 32, 297-301. [CrossRef] [PubMed]

79. Shah, K.V.; Daniel, R.W.; Simons, J.W.; Vogelstein, B. Investigation of colon cancers for human papillomavirus genomic sequences by polymerase chain reaction. J. Surg. Oncol. 1992, 51, 5-7. [CrossRef] [PubMed]

80. Pérez, L.O.; Abba, M.C.; Laguens, R.M.; Golijow, C.D. Analysis of adenocarcinoma of the colon and rectum: Detection of human papillomavirus (HPV) DNA by polymerase chain reaction. Colorectal Dis. 2005, 7, 492-495. [CrossRef]

81. Grinstein, S.; Preciado, M.V.; Gattuso, P.; Chabay, P.A.; Warren, W.H.; De Matteo, E.; Gould, V.E. Demonstration of Epstein-Barr Virus in Carcinomas of Various Sites. Cancer Res. 2002, 62, 4876-4878.

82. Morewaya, J.; Koriyama, C.; Akiba, S.; Shan, D.; Itoh, T.; Eizuru, Y. Epstein-Barr virus-associated gastric carcinoma in Papua New Guinea. Oncol. Rep. 2004, 12, 1093-1098. [CrossRef] [PubMed]

83. Nishigami, T.; Kataoka, T.R.; Torii, I.; Sato, A.; Tamura, K.; Hirano, H.; Hida, N.; Ikeuchi, H.; Tsujimura, T. Concomitant adenocarcinoma and colonic non-Hodgkin's lymphoma in a patient with ulcerative colitis: A case report and molecular analysis. Pathol. Res. Pract. 2010, 206, 846-850. [CrossRef]

84. Wong, N.A.; Herbst, H.; Herrmann, K.; Kirchner, T.; Krajewski, A.S.; Moorghen, M.; Niedobitek, F.; Rooney, N.; Shepherd, N.A.; Niedobitek, G. Epstein-Barr virus infection in colorectal neoplasms associated with inflammatory bowel disease: Detection of the virus in lymphomas but not in adenocarcinomas. J. Pathol. 2003, 201, 312-318. [CrossRef] [PubMed]

85. Jalouli, J.; Jalouli, M.M.; Sapkota, D.; Ibrahim, S.O.; Larsson, P.-A.; Sand, L. Human Papilloma Virus, Herpes Simplex Virus and Epstein Barr Virus in Oral Squamous Cell Carcinoma from Eight Different Countries. Anticancer Res. 2012, 32, 571-580.

86. Jiang, R.; Ekshyyan, O.; Moore-Medlin, T.; Rong, X.; Nathan, S.; Gu, X.; Abreo, F.; Rosenthal, E.L.; Shi, M.; Guidry, J.T.; et al. Association between human papilloma virus/Epstein-Barr virus coinfection and oral carcinogenesis. J. Oral Pathol. Med. 2015, 44, 28-36. [CrossRef] [PubMed]

87. Polz-Gruszka, D.; Stec, A.; Dworzański, J.; Polz-Dacewicz, M. EBV, HSV, CMV and HPV in Laryngeal and Oropharyngeal Carcinoma in Polish Patients. Anticancer Res. 2015, 35, 1657-1661.

88. Whitaker, N.J.; Glenn, W.K.; Sahrudin, A.; Orde, M.M.; Delprado, W.; Lawson, J.S. Human papillomavirus and Epstein Barr virus in prostate cancer: Koilocytes indicate potential oncogenic influences of human papillomavirus in prostate cancer. Prostate 2013, 73, 236-241. [CrossRef]

89. Epstein, M.A.; Henle, G.; Achong, B.G.; Barr, Y.M. Morphological and biological studies on a virus in cultured lymphoblasts from burkitt's lymphoma. J. Exp. Med. 1965, 121, 761-770. [CrossRef] [PubMed] 
90. Al Moustafa, A.-E.; Cyprian, F.S.; Al-Antary, N.; Yasmeen, A. High-Risk Human Papillomaviruses and Epstein-Barr Virus Presence and Crosstalk in Human Oral Carcinogenesis. In Development of Oral Cancer: Risk Factors and Prevention Strategies; $\mathrm{Al}$ Moustafa, A.-E., Ed.; Springer International Publishing: Cham, Germany, 2017; pp. 83-94. [CrossRef]

91. Gupta, I.; Ghabreau, L.; Al-Thawadi, H.; Yasmeen, A.; Vranic, S.; Al Moustafa, A.-E.; Malki, M. Co-Incidence of Human Papillomaviruses and Epstein-Barr Virus is Associated with High to Intermediate Tumor grade in Human Head and Neck Cancer in Syria. Front. Oncol. 2020, 10, 1016. [CrossRef]

92. Akhtar, S.; Vranic, S.; Cyprian, F.S.; Al Moustafa, A.E. Epstein-Barr Virus in Gliomas: Cause, Association, or Artifact? Front. Oncol. 2018, 8, 123. [CrossRef]

93. Al Moustafa, A.-E.; Chen, D.; Ghabreau, L.; Akil, N. Association between human papillomavirus and Epstein-Barr virus infections in human oral carcinogenesis. Med. Hypotheses 2009, 73, 184-186. [CrossRef]

94. Guidry, J.T.; Birdwell, C.E.; Scott, R.S. Epstein-Barr virus in the pathogenesis of oral cancers. Oral Dis. 2018, 24, 497-508. [CrossRef]

95. Vranic, S.; Cyprian, F.S.; Akhtar, S.; Al Moustafa, A.-E. The Role of Epstein-Barr Virus in Cervical Cancer: A Brief Update. Front. Oncol. 2018, 8, 113. [CrossRef] [PubMed]

96. Fernandes, Q.; Gupta, I.; Vranic, S.; Al Moustafa, A.E. Human Papillomaviruses and Epstein-Barr Virus Interactions in Colorectal Cancer: A Brief Review. Pathogens 2020, 9, 300. [CrossRef] [PubMed]

97. Guidry, J.T.; Scott, R.S. The interaction between human papillomavirus and other viruses. Virus Res. 2017, 231, 139-147. [CrossRef]

98. Cyprian, F.S.; Al-Farsi, H.F.; Vranic, S.; Akhtar, S.; Al Moustafa, A.-E. Epstein-Barr Virus and Human Papillomaviruses Interactions and Their Roles in the Initiation of Epithelial-Mesenchymal Transition and Cancer Progression. Front. Oncol. $2018,8,111$. [CrossRef] [PubMed]

99. Ferreira, A.R.; Ramalho, A.C.; Marques, M.; Ribeiro, D. The Interplay between Antiviral Signalling and Carcinogenesis in Human Papillomavirus Infections. Cancers 2020, 12, 646. [CrossRef]

100. Akil, N.; Yasmeen, A.; Kassab, A.; Ghabreau, L.; Darnel, A.D.; Al Moustafa, A.E. High-risk human papillomavirus infections in breast cancer in Syrian women and their association with Id-1 expression: A tissue microarray study. Br. J. Cancer 2008, 99, 404-407. [CrossRef]

101. Lawson, J.S.; Glenn, W.K. Multiple oncogenic viruses are present in human breast tissues before development of virus associated breast cancer. Infect. Agent Cancer 2017, 12, 55. [CrossRef]

102. Gupta, I.; Jabeen, A.; Vranic, S.; Al Moustafa, A.-E.; Al-Thawadi, H. Oncoproteins of high-risk HPV and EBV cooperate to enhance cell motility and invasion of human breast cancer cells via Erk1/Erk2 and beta-catenin signaling pathways. Front. Oncol. 2021. In Press. [CrossRef]

103. Darnel, A.D.; Wang, D.; Ghabreau, L.; Yasmeen, A.; Sami, S.; Akil, N.; Al Moustafa, A.E. Correlation between the presence of high-risk human papillomaviruses and Id gene expression in Syrian women with cervical cancer. Clin. Microbiol. Infect. 2010, 16, 262-266. [CrossRef] [PubMed]

104. Aboulkassim, T.; Yasmeen, A.; Akil, N.; Batist, G.; Al Moustafa, A.-E. Incidence of Epstein-Barr virus in Syrian women with breast cancer: A tissue microarray study. Hum. Vaccines Immunother. 2015, 11, 951-955. [CrossRef] [PubMed] 